FACTA UNIVERSITATIS

Series: Economics and Organization Vol. 16, $\mathrm{N}^{\mathrm{o}} 1,2019$, pp. 1 - 12

https://doi.org/10.22190/FUEO1901001M

Original Scientific Paper

\title{
SECTORAL STRUCTURE OF BANK LOAN PORTFOLIOS: A SINGLE COUNTRY EXPLORATORY STUDY
}

\author{
UDC 336.77
}

\author{
Srđan Marinković ${ }^{1}$, Jelena Minović \\ ${ }^{1}$ University of Niš Faculty of Economics, Niš, Serbia \\ ${ }^{2}$ Institute of Economic Sciences, Belgrade, Serbia
}

\begin{abstract}
The paper explores time-varying nature of sectoral composition of bank domestic credit to private sector. Bank credit to private sector could be roughly divided into household loans and business (enterprise) loans. The composition appears to have significant influence on economic growth. Nevertheless, thus far it has been an overly neglected issue in financial theory. The paper focuses on determinants of household to total domestic private loans ratio in Serbian banking industry based on monthly time series from the last fourteen years. We found that both credit supply and credit demand determinants influence the sectoral composition.
\end{abstract}

Key words: household and business loans, bank credit to private sector, Serbian banking industry, time series analysis

JEL Classification: G21, E51, O16, C22

\section{INTRODUCTION}

It is widely agreed that financial development has strong influence on economic growth. Bank credit (to GDP) and bank credit to private sector are well-established indicators of financial development and also transition success (Scholtens, 2000). The first indicator is used to represent so called financial deepness (Beck et al., 2007), while the second one contains important information about the sectoral structure of bank credit portfolio. However, the sectoral structure of bank credit portfolio itself goes far beyond the proposed framework in the majority of studies concerning bank credit to private sector. Expressed as an aggregate measure, bank credit to private sector hides important information.

Received December 17, 2018 / Accepted February 18, 2019

Corresponding author: Srđan Marinković

Faculty of Economics Niš, Trg kralja Aleksandra 11, 18000 Niš, Serbia

E-mail: srdjan.marinkovic@gmail.com 
If we allow ourselves some imprecision, private sector loans could be roughly divided into household loans and business (enterprise) loans. Bank credit to private sector composition, i.e. the ratio of household to business loans, varies internationally within wide boundaries. According to financial theory, the structure itself influences the growth potential (Beck et al., 2012), hence it becomes important policy issue.

The aim of this study is to explore the reasons behind the time-varying nature of sectoral structure of loan portfolio of commercial banks in Serbia. Although we could not find any similar research to be the ground for our study, the opposite is true for guidelines in our search for determinants which were spread throughout the financial theory. To the best of our knowledge, this is the first attempt to explore the determinants of the loan portfolio structure in a single-country framework.

The remaining part of this paper is structured as follows. We begin in Section 2 with a review of literature on determinants and effects of bank credit to domestic private sector, and specifically its composition. Section 3 describes the dataset. Section 4 proceeds with the description of research methodology, results, as well as the discussion of main findings. Finally, section 5 presents a conclusion.

\section{LITERATURE REVIEW}

It is theoretically understood that development of financial sector, especially banks, has a vital role for economic activity (Goldsmith, 1969; Levine and Zervos, 1998; Rajan and Zingales, 2003), and the findings are well documented in a vast number of research papers (King and Levine, 1993; Demirgüç-Kunt and Maksimovic, 1998). For decades now, financial science relies on several indicators in order to assess the level of development of banking sector or transition success. So far, the best candidates have been total bank credit and credit to private sector (Anderson and Kegels, 1998; Scholtens, 2000; Hermes and Lensink, 2000; Beck et al. 2007). Both indicators are usually recalculated so as to present a share of GDP. Expressed in that way, the indicators become useful for international comparisons. If a country has a credit to GDP figure close to its peers (best-performers) it is then considered financially developed. There is no absolute limit of this ratio. Interestingly, record values of this ratio may mean well developed banking sector, but also dangerous tendencies that may lead to a credit crisis and economy overheating. This is especially true if the high level is accompanied with the latest records of steep rise of credit to GDP ratio (for a review see Marinković, 2015). Thus, both an increase and a decrease of this ratio may be assessed as a shift toward or shift away from the equilibrium.

The total bank credit figures may mask extremely different developments. In a nutshell, the total bank credit volume consists of bank credit to public and private sector. If a public sector receives comparably high share of total bank domestic credit it is considered suboptimal. It is often a consequence of under-developed private sector, hypertrophy of public sector and government spending, crowding out effect etc. On the other hand, a turn to private sector is traditionally considered a favorable development, since it may indicate discontinuation of financial and political relationship between credit providers and a local government, inherited from the past, more finance for productive investments, etc.

The stream of literature that investigates credit to private sector tells barely something about the structure of this aggregate (Cottarelli et al., 2005; Djankov et al., 2007). Moreover, 
the literature on determinants of the sectoral structure of loan portfolio is nothing but scarce. There are just a few papers that investigate this issue. The paper of Beck et al. (2012) is developed in multi-country framework and sheds some light on possible macroeconomic and institutional determinants able to explain cross-country variations in the sectoral structure of loan portfolio. The authors found legal origin and religious composition factors that influence both financial development and credit composition to household and business (enterprise) sector. On the other hand, the composition itself seems to have influence on economic growth, i.e. enterprise credit is found positively associated with the growth and income inequality reduction, while household credit is found unrelated.

Table 1 Household credit: international comparisons

\begin{tabular}{lcc}
\hline & Bank credit to GDP & Household credit share \\
\hline Developing countries & & \\
Bulgaria & 0.219 & 0.340 \\
Egypt & 0.446 & 0.167 \\
India & 0.219 & 0.287 \\
Indonesia & 0.252 & 0.324 \\
Macedonia & 0.187 & 0.249 \\
Mexico & 0.186 & 0.532 \\
Pakistan & 0.225 & 0.224 \\
Russia & 0.147 & 0.223 \\
Thailand & 1.226 & 0.184 \\
Turkey & 0.179 & 0.355 \\
Uruguay & 0.392 & 0.505 \\
\hline Developed countries & & \\
Belgium & 0.744 & 0.578 \\
Canada & 0.962 & 0.804 \\
Czech Republic & 0.484 & 0.352 \\
Denmark & 0.894 & 0.851 \\
France & 0.850 & 0.601 \\
Germany & 1.053 & 0.380 \\
Japan & 1.549 & 0.309 \\
Korea & 0.698 & 0.552 \\
Netherlands & 1.639 & 0.616 \\
Slovenia & 0.340 & 0.293 \\
Switzerland & 1.603 & 0.623 \\
United Kingdom & 1.269 & 0.561 \\
\hline Of which market-based & & 0.764 \\
United States & 0.498 & \\
\hline
\end{tabular}

Source: Beck et al. (2012), Table 1.

The sectoral structure of bank credit to private sector also seems to have an important effect on trade balance. Buyukkarabacak and Krause (2009) found a strong influence of household loans on trade deficits in a multicountry framework. The rationale for this regularity is the fact that household demand, financed by bank credit, increases consumption of consumer goods which are at least partly imported. The effect is as strong 
as ardent is a country struggle to sustain foreign trade in balance. However, although business loans may also increase demand for consumer goods (in case of trade or tourism industry) in a major part it will end up with an increase of import of non-consumer goods like raw material or productive equipment. Therefore, if a country suffers from chronic and persistent trade deficits and also is prone to currency crisis, it should put on its radar the level of household loans as a policy issue.

The table above (1) presents data on bank credit to GDP and household credit share in total domestic private sector credit (a sum of household and business credit). All the data are from the Beck et al. (2012). The original list of countries is here shortlisted, but still gives a valuable overview of cross-country variety. It brings a basic idea that although the share of household credit varies from one country to another, it appears as a regularity that more developed countries have the structure of credit portfolio more inclined to household loans. Within the developed countries subsample, it is also the case that in market-based financial systems (e.g. the US) banks are additionally prone to finance households. An obvious explanation is that in such systems business finance in large part goes through financial markets (primarily bond and commercial paper markets).

\subsection{Risk-return differences of household and business loans: searching for determinants}

Beside the determinants that exert their influence on household/business loan structure from the sphere of overall financial and institutional developments, there have to be some other important elements that might explain either cross-country differences or the changing nature of bank loan portfolio structure.

If we delve into the drivers of demand and supply for different types of credit, we can observe some notable differences among the types of loans. With the supply side influences, we cover the reasons why credit providers may favor household credit over business credit and vice versa. First and foremost, do banks charge customers more on household loans relative to business loans? There is not an easy and straightforward answer to this question. Interest rates charged on prime business customers are usually comparable to yield that banks earn on riskfree assets (government securities) and, depending on economic conditions, they could be marginally higher or even lower than the yield on government securities. On the other hand, the highest rates are charged on most flexible credit arrangements granted to households (e.g. credit cards overdue). They could be several times higher that rates charged to a prime customer business loan.

However, information about return means almost nothing if it is not adjusted for risk. How about risk differences? Let us turn to the other side of risk-return relationship. Is there any hard fact that household loans could be considered less risky than business loans? At this moment we would underline a rule that helps link mutual interdependence between creditworthiness of business and household units. Namely, relative ability of those two sectors to repay bank debt depends on some institutional features. For instance, salary is the most important financial source for households to repay bank debt, while it is at the same time important business expense. Some institutional features may rank salaries high on the priority list among business expenses, make it rather fixed costs. If there is a minimum wage regulation, then this ,priority effect” could be even more pronounced. Exactlythis priority may make household loans less risky than business loans, at least in hostile business 
environment. Other differences are assets available for collateral; net wealth records, personal bankruptcy regulation etc. A major part of business assets belongs to „specific assets" (non-pledgeable), e.g. know-how, tailor-made or specific purpose equipment (Holmström and Tirole, 2011), while household assets often can be transferable (e.g. houses and apartments) and better suited to collateral purposes. In terms of net wealth records the things are in favor of enterprises, which regularly have to keep record of all business transactions, assets, liabilities and net worth.

From the financial intermediation theory (Bhattacharya and Thakor, 1993) it comes clearly that a financial intermediary provides two types of services. They are brokers and asset transformers. In doing its transformation services, a financial intermediary transforms maturity, divisibility, default risk and liquidity. By doing this, financial intermediaries often expose themselves to various kinds of risk. Let us take into consideration maturity differences. Since asset-liability maturity mismatch is a crucial source of interest rate risk and liquidity risk in banks, providing that average maturity of liabilities is a short-term one, the assets that are of longer maturity will expose credit provider to comparably higher risk. Household and business loans are inhomogeneous in many relevant features: in terms of maturity, amounts, credit risk etc. However, if average household and business loans differ in those features, sectoral credit composition will make difference for banks risk exposure.

An important distinguishing element may be also different behavior of demand for household vs. business loans during some challenging phases of business cycle. For example, in crisis conditions or business recessions the demand for business loans is likely to be weaker. Some business units will postpone financing of new and complex business undertakings and remain dedicated only to current assets financing. Moreover, for business units bank credit is just one way to finance expenditures and development. On the other hand, households almost exclusively rely on banking loans and often borrow out of necessity besides opportunity. Therefore, we could expect that the credit demand in business sector is more interest rate elastic relative to that of household sector.

The elements that we have explored above shape risk-return relationship for a typical household and business loan. Unfortunately, many of those elements are not easy to test empirically. In the next section we will try to sample a set of operable indicators based on the inputs from financial theory.

\section{DATASET}

Our dataset comprises a dependent variable and a set of explanatory variables time series. Some data were available as early as year 2004. However, there were no records of full set of variables before 2005. Therefore, in this study data spans from January 2005 to November 2018. For all variables the source of data is National Bank of Serbia statistics, which is available publically. The ultimate data source for the dependent variable is Commercial banks assets and liabilities composition time series.

The dependent variable is defined as a share of household loans in total domestic private sector loans (HTL). Since domestic private sector loans excludes banks' claims on non-residents (foreign exchange reserves and other foreign assets), national government (central and local government units) and various claims on National Bank of Serbia (cash and both local and foreign currency deposits, repo stock etc.), this category generally 
consists of bank claims on household and business sector. Business loans include several sub-categories (companies, public enterprises and other financial organizations), while household loans beside household loans category includes yet only loans to non-profit and other organizations. This latest sub-category has a minor influence on the structure.

Unfortunately, no variable able to represent demand side determinants is available with monthly frequency. Natural candidates would be household consolidated income and an adequate proxy variable for business sector financial condition. In order to capture at least some influence of changes in sectoral credit demand, we introduced a savings variable. It is clear that bank savings is just a part of total financial wealth of households and even smaller part of total household wealth. However, bank savings records still represent dynamics of overall financial position of households, assuming that the structure of household wealth remains constant overtime. The financial position itself indicates capacity to take out and repay debt, and can be very close to free household income (income in excess of regular consumption). The idea to include savings volume as a predictor into the regression model is also based on the assumption that household savings is primarily used to finance various forms of household loans. The assumption can be justified by the fact that household loans are better matched with savings in terms of divisibility (amounts), maturity and liquidity features. However, level data on savings are clearly trended. Therefore, we rearranged the variable so as to represent a share of savings in total banks assets and/or liabilities. This way, saving to total assets ratio (STA) represents a mixture of demand and supply side determinants of sectoral structure of bank credit to domestic private sector.

The next variable that entered the model is nominal foreign exchange rate (NER), expressed as RSD vis-à-vis EUR. A rationale for regressing the structure of commercial banks loan portfolio on exchange rate is to control for the effect that a change in exchange rate may have on the volume of different claims. Namely, because of high level of financial euroization, a volume of loan portfolio when expressed in reporting currency (RSD) becomes highly influenced by the exchange rate. If loans granted to business units differ from loans granted to households in terms of euroization extent, it may influence the very structure of loan portfolio. As we expected, the data on currency structure (includes also contracted hedge) of credit to household and credit to business sector revealed comparably higher share of credit euroization in business loans. Based on data from July 2008 onwards, business sector has an average share of local currency (nonhedged) claims of $22.7 \%$, with extreme values of $9.3 \%$ to $33.4 \%$. At the same time, household sector reports $34.3 \%$ of local currency claims (min. $20.7 \%$, max. 50.9\%).

Propensity of banks to prioritize households' loans over business loans belongs to socalled supply-side determinants. In order to represent at least one determinant of this kind, we introduced a variable constructed as a difference between interest rate charged on household loans and interest rate charged on business loans. In order to avoid negative data, the variable is expressed as a ratio of the rate charged on household to the rate charged on business loans (IRR). If available, the rates were average volume weighted interest rates available from National Bank of Serbia (NBS) official statistical database. The data are annual rates and expressed in percentage. This is exactly where we faced the biggest challenge in sampling the data. Namely, the scope and format of the interest rate statistics of NBS were changed radically starting for reporting year 2010. The statistics for the previous period (January 2005 to June 2011) contains no information on average rate charged on total credit granted either to household or business sector. The report concerns only credits 
granted in local currency, disaggregated based on maturity criterion and types of credit. Therefore, for this period, instead of aggregate data we used a sort of representative data. As a representative for a household loan (rate) we took short-term "household loan" in the local currency, while for a business loan we took the rate charged on "other lending" since the other two available types (export and agricultural loans) were less likely to represent a typical business loan. It is also a short-term local currency bank asset.

NBS interest rates statistics for the period starting from September 2010 onwards is more detailed and consistent. The report contains data on average volume weighted interest rate charged on all types of household loans (housing, consumer, cash and other loans) and takes into account currency and maturity composition. It is the same with business loans (loans to non-financial enterprises), which comprises main types or purposes (current assets, export, investment and other) disaggregated according to the range of currencies and maturities. Because the interest rate data available for different periods were inconsistent to each other, we have opted for separate specification (regressions). Although the regression model that we have applied here is generally the same, the first specification deals with the data from 2005 to 2010, while the second one operates with the data for the later period.

Table 2 Descriptive statistics

\begin{tabular}{|c|c|c|c|c|c|c|c|}
\hline Series & Mean & Median & SD & Skewness & Kurtosis & $\mathrm{J}-\mathrm{B}$ & Prob \\
\hline \multicolumn{8}{|c|}{ Time series Y2005-Y2010 } \\
\hline HTL & 0.337 & 0.361 & 0.055 & -1.285 & 3.285 & 20.058 & 0.000 \\
\hline STA & 0.229 & 0.229 & 0.021 & 0.230 & 2.111 & 3.008 & 0.222 \\
\hline NER & 87.809 & 84.873 & 8.834 & 0.798 & 2.499 & 8.395 & 0.015 \\
\hline IRR & 2.177 & 2.149 & 0.458 & 0.162 & 2.283 & 1.856 & 0.395 \\
\hline \multicolumn{8}{|c|}{ Time series Y2011-Y2018 } \\
\hline HTL & 0.390 & 0.390 & 0.040 & 0.329 & 1.923 & 6.242 & 0.044 \\
\hline STA & 0.304 & 0.311 & 0.014 & -0.960 & 2.595 & 15.076 & 0.000 \\
\hline NER & 116.142 & 118.168 & 6.662 & -1.093 & 3.412 & 19.390 & 0.000 \\
\hline IRR & 2.012 & 2.118 & 0.535 & -0.106 & 2.132 & 3.128 & 0.209 \\
\hline
\end{tabular}

Note: SD stands for Standard Deviation, J-B for Jarque-Bera.

Source: Authors' estimation

Based on visual data presentation and scatter plots (Appendix, table 5) there is a rather good fit between the regressand and almost all regressors unilaterally. Quite similar distribution of pair points in scatter plots of household to total domestic loans ratio (HTL) vs. savings to total assets ratio (STA) and HTL vs. NER (nominal exchange rate) indicates that there must be a joint influence of some variable, e.g. it may mean that nominal exchange rate has strongly influenced savings ratio. This was why we joined a scatter plot of STA vs. NER. This scatter plot indicates rather high correlation between those variables. A rationale for this regularity is strong influence of nominal exchange rate on savings to total assets ratio (STA). Knowing that high share of savings volume is foreign currency (largely EUR) denominated or indexed savings, while it is significantly less in terms of total banks' assets (ratio denominator), it comes expected that variability of STA becomes largely driven by exchange rate changes.

The table 2 presents descriptive statistics for time series. As already underlined, the data for each variable were subsampled into two continuing time series (Y2005-Y2010 and Y2011-Y2018) with no overlap, because we had to run separate regressions for two 
periods. Based on Jarque-Bera test, all the variables, with exception of interest rate ratio (IRR), show normal distribution. However, for this kind of regressions normality of distributions is a desirable but not necessary condition.

\section{RESEARCH METHODOLOGY, RESUlTS AND DisCUSSION}

Before performing the regression analysis, we transformed all variables in logarithm values, and tested the stationarity of all time-series variables (Table 3). In both periods, variables household to total (domestic private) loans (HTL), savings to total assets (STA), and nominal exchange rate (NER) are nonstationary, while the variable interest rate ratio (IRR) is stationary. Therefore, we transformed the nonstationary variables in stationary variables using the first differences $(\Delta)$ of level data.

Table 3 Unit root tests

\begin{tabular}{lcccc}
\hline Series & $\begin{array}{c}\text { ADF test } \\
\text { statistics }\end{array}$ & $\begin{array}{c}\text { Significance } \\
\text { level }\end{array}$ & $\begin{array}{c}\text { Critical value for } \\
\text { the level }\end{array}$ & $\mathrm{H}_{0}$ \\
\hline \multicolumn{2}{l}{ Time series Y2005-Y2010 } & & & \\
HTL & -1.540 & 0.05 & -3.473 & cannot be rejected \\
STA & -2.992 & 0.05 & -3.473 & cannot be rejected \\
NER & -1.496 & 0.05 & -3.473 & cannot be rejected \\
IRR & -4.255 & 0.05 & -3.473 & rejected \\
$\Delta$ HTL & -8.019 & 0.05 & -3.473 & rejected \\
$\Delta$ STA & -9.111 & 0.05 & -3.473 & rejected \\
$\Delta$ NER & -9.451 & 0.05 & -3.473 & rejected \\
\hline Time series Y2011-Y2018 & & & \\
HTL & -2.726 & 0.05 & -3.459 & cannot be rejected \\
STA & -1.495 & 0.05 & -3.459 & cannot be rejected \\
NER & -1.347 & 0.05 & -3.459 & cannot be rejected \\
IRR & -7.294 & 0.05 & -3.459 & rejected \\
$\Delta$ HTL & -9.720 & 0.05 & -3.459 & rejected \\
$\Delta$ STA & -10.606 & 0.05 & -3.459 & rejected \\
$\Delta$ NER & -9.615 & 0.05 & -3.459 & rejected \\
\hline
\end{tabular}

Note: The null hypothesis $\mathrm{H}_{0}$ : unit root exists in the process; the alternative hypothesis: the process is stationary. $\Delta$ denotes first differences of variables. Schwarz automatic selection criterion of the lag length has been used for the unit root tests. Augmented Dickey Fuller test (ADF) is test statistics for a unit root.

Source: Authors' estimation

After having rearranged the data in order to satisfy stationarity condition of time series, the regression analysis followed (Table 4). We have two regressions: one is for the period 2005M01-2010M12, and second is for the period 2011M01-2018M10. Both regressions were estimated with time series of monthly frequency. 
Table 4 Regression results and diagnostics

\begin{tabular}{lcc}
\hline & Regression 1 & Regression 2 \\
\hline Savings to total assets (STA) & 0.093 & $\mathbf{0 . 2 0 8}$ \\
& {$[0.071]$} & {$[0.121]$} \\
Nominal exchange rate (NER) & 0.047 & -0.046 \\
& {$[0.072]$} & {$[0.091]$} \\
Interest rate ratio (IRR) & $-\mathbf{0 . 0 3 8} * *$ & $\mathbf{0 . 0 0 8 * *}$ \\
& {$[0.009]$} & {$[0.003]$} \\
Constant & $\mathbf{0 . 0 3 6 * *}$ & -0.002 \\
& {$[0.007]$} & {$[0.002]$} \\
Diagnostics & & \\
$R^{2}$ & 0.243 & 0.100 \\
F & 7.177 & 3.285 \\
& $(0.000)$ & $(0.024)$ \\
BG(5) & 3.944 & 1.051 \\
& $(0.004)$ & $(0.393)$ \\
Q(10) & 48.034 & 9.907 \\
& $(0.000)$ & $(0.449)$ \\
\hline
\end{tabular}

Note: Standard errors of estimated parameters are given in square brackets, and $\mathrm{p}$-values are in parenthesis. Values of determination coefficient $\left(\mathrm{R}^{2}\right)$, F-test for regression significance, Ljung-Box (Q-test) statistics of residuals, and Breusch-Godfrey's (BG) test of serial correlation of fifth order are given. $* *$ denotes statistical significance at $1 \%$ level; * denotes statistical significance at $10 \%$. Source: Authors' estimation

Both regressions are statistically significant according to the $F$-test. However, second regression has a satisfactory statistical property, in the sense that, according to the Breusch-Godfrey (BG) test, there is no autocorrelation of fifth order in the residuals of this model. Similarly, according to the Ljung-Box statistics (Q-test) there is no autocorrelation of tenth order in the residuals of this model. In second regression, two explanatory variables (STA and IRR) are positive and statistically significant at the 0.1 level and at 0.01 level respectively. However, first regression does not have satisfactory statistical property according to both the BG test and the Q-test. In first regression, constant term is positive and statistically significant at the 0.01 level, while IRR is negative and statistically significant at the 0.01 level.

Determination coefficient is relatively small in both regressions. For instance, in second regression $R^{2}$ is barely 0.1 indicating that only $10 \%$ of variance of the dependent variable (HTL) can be explained with the set of explanatory variables. Such results do not diminish quality of inference about explanatory power of each tested statistically significant variable. It only warns that the model specifications are not reliable for any prognostic purpose, for instance because of omitted variables possibility. 
For further discussion, we will focus on second regression, since this one has necessary statistical properties. Firstly, a change in nominal exchange rate has no direct influence on sectoral credit structure. It might be that the variable has some power to explain the structure but it likely goes via saving to total assets ratio. Savings to total assets ratio itself is related to household loans share in total domestic private loans exactly as we would predict. The higher share of household savings in bank total assets, the higher would be a share of household loans over the share of business loans. Interest rate ratio has the same way of influence (positive sign of the regression coefficient). The variable has a direct positive influence on the dependent variable, which means that if the difference between interest rates charged on household loans and business loans increases, banks will favour more lucrative type of loans. Nevertheless, the fact that banks prioritize household loans does not have to bring eventually a change in bank credit portfolio. For that to be in place, households must accept the increase in relative credit costs. The latest finding probably might be explained with assumed difference in interest rate elasticity of credit demand between household and business sectors.

\section{CONCLUSION}

The causal relationship between financial development and economic growth remains one of the most frequently studied topics positioned on the borderline of macroeconomics and financial economics. The main contribution of this strand of literature is economic policy relevance of bank credit activity, especially credit to private sector. However, one specific issue remains on the margins of interest of scientific community. This is the composition of bank credit to private sector; how much of this credit activity is directed to households vs. enterprises.

This paper is aimed to fill a gap in the literature concerning drivers of the composition within a single country framework. To the best of our knowledge, this is the first investigation of this kind. The paper brings some empirical evidence but it is equally intriguing in its attempt to assemble ideas concerning risk-return differences of household and business loans, which may shape demand and supply for those loan types. Unfortunately, data availability limited our intents to undergo appropriate empirical tests in order to verify our cogitations.

Nevertheless, the regression analysis confirms that a share of household loans in bank domestic credit to private sector is related to both credit supply and credit demand determinants. We introduced one proxy for each group of determinants and found the share of household savings in total bank assets/liabilities (STA), as well as the interest rates margin charged on household over business loans (IRR) statistically significant. Moreover, the direction of influence in both cases complies with the theory prediction. Somewhat disappointing regression fit indicates that there are likely some determinants remaining out of the model.

Acknowledgement: The authors are grateful to the Ministry of Education, Science and Technological Development of the Republic of Serbia for the funds and support that made this research possible (OI 179066; OI 179015; III 47009). 


\section{REFERENCES}

Anderson, W.R. \& Kegels, C. (1998). Transition banking: Financial development of Central and Eastern Europe. Oxford: Clarendon Press.

Bhattacharya, S. \& Thakor, A. (1993). Contemporary banking theory. Journal of Financial Intermediation, 3 , $2-50$.

Beck, T., Büyükkarabacak, B., Rioja, K.F. \& Valev, T.N. (2012). Who gets the credit? And does it matter? Household vs firm lending across countries. The B.E. Journal of Macroeconomics, 12 (1), 1-46 doi: $10.1515 / 1935-1690.2262$

Beck, T., Demirgüç-Kunt, A. \& Martinez Peria, S.M. (2007). Reaching out: Access to and use of banking services across countries. Journal of Financial Economics, 85, 234-266.

Buyukkarabacak, B. \& Krause, S. (2009). Studying the effects of household and firm credit on the trade balance: The composition of funds matters. Economic Inquiry, 47 (4), 653-666 doi: 10.1111/j.14657295.2008.00173x

Cottarelli, C., Dell'Ariccia, G. \& Vladkova-Hollar, I. (2005). Early birds, late risers, and sleeping beauties: Bank credit growth to the private sector in Central and Eastern Europe and in the Balkans. Journal of Banking and Finance, 29, 83-104.

Demirgüç-Kunt, A. \& Maksimovic, V. (1998). Law, finance and firm growth. Journal of Finance, 53, 2107-2037.

Djankov, S., McLiesh, C. \& Shleifer, A. (2007). Private credit in 129 countries. Journal of Financial Economics, 84, 299-329.

Goldsmith, R.W. (1969). Financial structure and development. New Haven: Yale University Press.

Hermes, N. \& Lensink, R. (2000). Financial system development in transition economies. Journal of Banking and Finance, 24 (4), 507-524.

Holmström, B. \& Tirole, J. (2011). Inside and outside liquidity. Cambridge (MA): The MIT Press.

King, G.R., Levine, R. (1993). Finance, entrepreneurship, and growth: Theory and evidence. Journal of Monetary Economics, 32, 513-542.

Levine, R. \& Zervos, S. (1998). Stock markets, banks, and economic growth. American Economic Review, 88, 537-558.

Marinković, S. (2015). Managing the financial crisis: Credit crunch and response in Serbia. In: Thomas, M. \& Bojicic-Dzelilovic, V. (Eds.), Public policy making in the Western Balkans (pp. 171-196). Dordrecht: Springer Science+Business Media.

Rajan, G.R. \& Zingales, L. (2003). Saving capitalism from the capitalists. London: Random House Business Books.

Scholtens, B. (2000). Financial regulation and financial system architecture in Central Europe. Journal of Banking and Finance, 24 (4), 525-553.

\section{SEKTORSKA STRUKTURA KREDITNOG PORTFELJA BANAKA: ISTRAŽIVANJE NA PRIMERU JEDNE DRŽAVE}

U radu istražujemo varijabilitet sektorske strukture bankarskih kredita privatnom sektoru. Bankarske kredite privatnom sektoru pojednostavljeno delimo na kredite stanovništvu i kredite privredi. Iako se očekuje da sektorska struktura ima značajan uticaj na privredni rast, ovo pitanje je do sada ostalo zanemareno u finansijskoj teoriji. U radu se istražuju determinante učešća kredita stanovništvu u ukupnim domaćim kreditima privatnom sektoru u bankarskom sektoru Srbije na bazi vremenskih serija mesečnih podataka za poslednjih četrnaest godina. Utvrdili smo da na ovako definisanu sektorsku strukturu kreditnog portfelja banaka utiču kako determinante kreditne ponude tako i determinante kreditne tražnje.

Ključne reči: krediti stanovništvu i privredi, bankarski kredit privatnom sektoru, bankarski sektor Srbije, analiza vremenskih serija 


\section{APPENDIX}

Table 5 Dynamics of variables and scatter plots

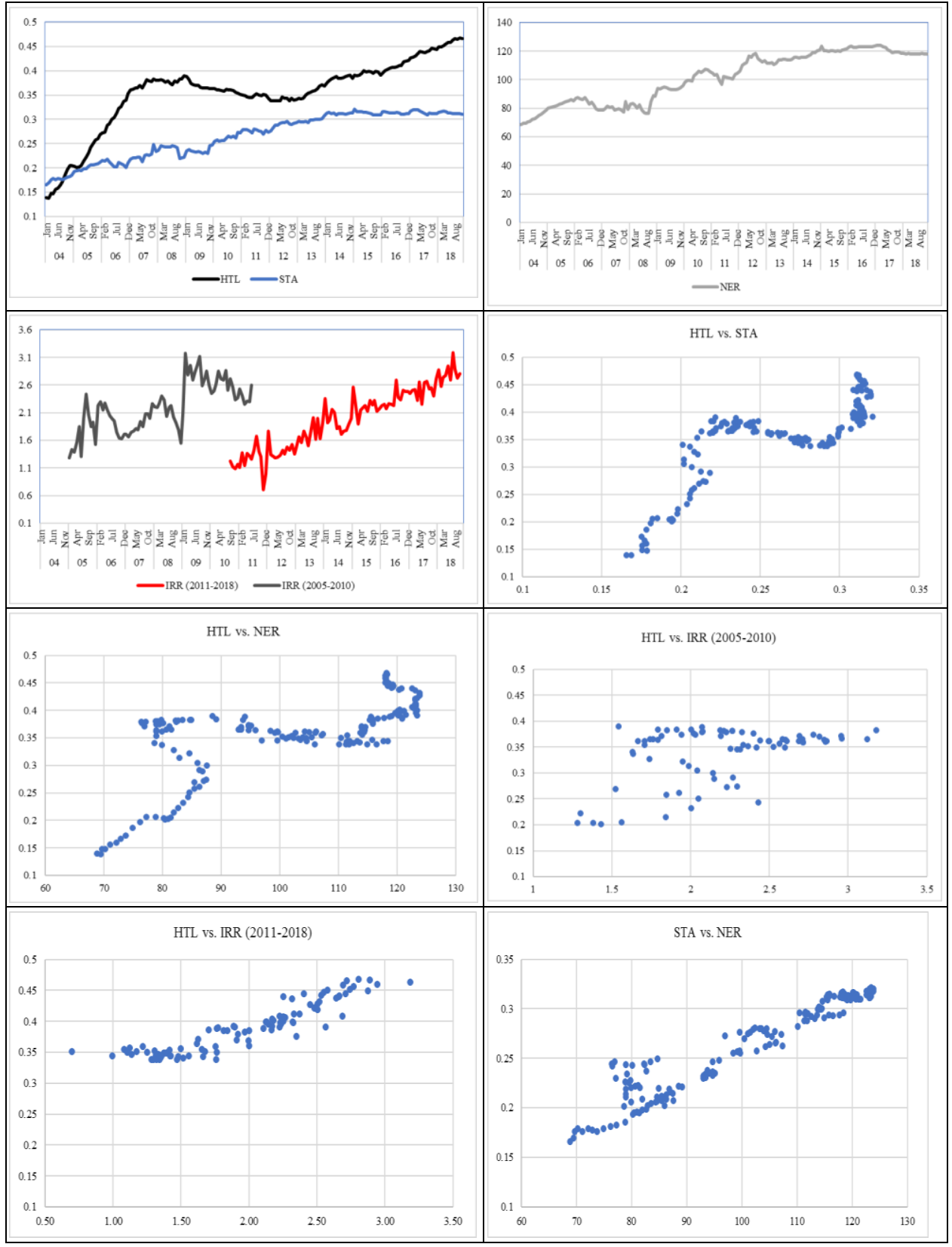

Source: Authors' calculation based on NBS statistics 